\title{
В. Нестеренко,
}

аспірант, методист ад'юнктури (аспірантури)

Академії Державної пенітенціарної служби

\section{ОКРЕМІ АСПЕКТИ ПІДБОРУ ТА ПІДГОТОВКИ ПЕРСОНАЛУ УСТАНОВ ВИКОНАННЯ ПОКАРАНЬ СПОЛУЧЕНИХ ШТАТІВ АМЕРИКИ}

\begin{abstract}
Постановка проблеми. Соціально-економічні й політичні перетворення, що відбуваються нині в Україні, зумовлюють необхідність формування якісно нового підходу до підготовки персоналу для потреб Державної кримінально-виконавчої служби України (далі - ДКВС України) та є невіддільною частиною реформування всієї системи органів державної влади загалом. Метою такої підготовки $є$ необхідність набуття фахових особистісних навичок i вмінь, потрібних для успішного виконання покладених на них завдань. Зважаючи на це, виникає підвищений інтерес до викладення позитивних здобутків світової практики вишколу персоналу пенітенціарних систем із метою імплементації міжнародних стандартів в освітні програми 3 підготовки фахівців установ виконання покарань (далі УВП) України.

Тому актуальність вивчення досвіду Сполучених Штатів Америки (далі - США) доцільна завдяки багаторічній провідній позиції цієї країни в формуванні професійної компетенції персоналу УВП. Проте щоб мати уявлення щодо основних засад організації діяльності персоналу УВП США, необхідно з'ясувати характерні особливості організаціі та функціонування пенітенціарної системи цієї країни.
\end{abstract}

Аналіз останніх досліджень i публікацій. Протягом усього періоду становлення вітчизняного кримінально-виконавчого законодавства структура УВП удосконалюється, а заходи виховного впливу на засудженого постійно змінюються, впроваджуючи гуманістичну парадигму розвитку пенітенціарної системи. Отже, щоб професійно опанувати ці заходи й вміти ними оперувати, українські науковці почали перейматися питаннями розвитку професійної компетентності персоналу УВП. Серед авторів, які займалися викладенням вказаної проблематики, слід згадати провідних вітчизняних і зарубіжних вчених, таких, як А. Галай, В. Міллер, Дж. Люкс, Д. Ягунова, I. Богатирьова, I. Яковець, К. Муравйова, М. Пузирьова, М. Сикала, О. Дука, О. Сахнік, Т. Денисову, Т. Нікола-

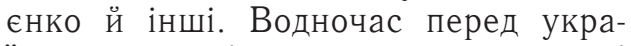
інським суспільством постають нові проблеми, пов'язані із запровадженням міжнародних стандартів у галузі виконання кримінальних покарань і діяльності органів та УВП, що тягне за собою зростання вимог до якості підготовки персоналу вищезазначених інституцій.

Формування цілей. Мета наукової статті полягає у вивченні й визначенні сучасних тенденцій розвитку пенітенціарної системи США, в тому числі в здійсненні порівняльного аналізу компонентів освітніх програм із підготовки персоналу УВП України й США, що дозволить запропонувати шляхи підвищення якості підготовки персоналу УВП ДКВС України. 
Виклад основного матеріалу. Розглядаючи характеристику пенітенціарної системи США, варто зазначити, що близько $5 \%$ від загальної кількості громадян США перебувають за гратами, й це складає приблизно $1 / 4$ всіх ув'язнених у світі. Приблизно один зі 107 дорослих американців перебуває за гратами. Ця кількість є майже в п'ять разів вищою за кількість ув'язнених в Англії, в сім разів більшою, ніж у Франції [6;13].

Зауважимо, що, хоча США досі займає перше місце за кількістю в'язнів на 100 тисяч населення, проте політика держави відносно пенітенціарної системи почала змінюватися. Передумовою зменшення кількості ув'язнених стала фінансова криза 2007 року й безрезультатність багаторічної кампанії по боротьбі з наркоторгівлею, а також й те, що за останні 10 років були проведені реформи на державному й федеральному рівнях. Серед державних реформ варто виділити внесення поправок до Рокфеллерівського Закону «Про наркотики» (eng. Rockefeller Drug Laws) від квітня 2009 року штату Нью-Йорк, де було замінено ув'язнення винного в дрібних злочинах, пов'язаних 3 обігом наркотиків, мінімальним покаранням на кшталт нагляду пробації або направлення порушника на медикаментозне лікування [17]. На федеральному рівні варто приділити увагу Закону «Про справедливе засудження» (eng. Fair Sentencing Act) від 03 серпня 2010 року [16], що нівелював різницю між торгівлею кокаїном та іншими порошковими наркотиками й мав задачу зменшити контингент ув'язнених. За результатами цих та інших реформ планується скоротити популяцію УВП США вдвічі до 2085.

У доповіді Бюро судової статистики (eng. Bureau of Justice Statistics), яке є структурним підрозділом Мін'юсту США, повідомляється, що згідно зі статистичними даними 2008-2018 років кількість ув'язнених зменшилася більш ніж на $10 \%$ у всіх в'язницях країни. Вперше з 1996 року був зафіксований показник 431 ув'язнений на 100000 осіб. На $28 \%$ відзначено зниження числа ув'язнених громадян афроамериканців, на $21 \%$ - громадян латиноамериканців і на $13 \%$ - білих громадян [2; 7]. Враховуючи вищезазначену статистику й той факт, що кількість засуджених із року в рік скорочується, ми бачимо позитивну динаміку й можемо припустити, що в пенітенціарній системі США вживаються правильні заходи виправлення та стимулювання ув'язнених до законослухняної поведінки.

Також варто зазначити, що причинами підвищення стандартів і вимог до підготовки персоналу пенітенціарної системи США є: зменшення кількості ув'язнених і скорочення кількості УВП, що приводить до більшої конкуренції серед співробітників на заняття вакантної посади; збільшення грошового забезпечення персоналу УВП. Слід зауважити, що зараз в УВП США існує велика кількість посад із різними критеріями щодо їх комплектування.

На нашу думку, така позиція щодо формування кадрового резерву й наявності конкуренції між кандидатами на посаду слушна, оскільки освітні вимоги, щоб стати посадовою особою, відповідальною за виправлення (далі - виправник, eng. Corrections officer), залежать від того, в якому підпорядкуванні $€$ та чи інша установа (федеральному, на рівні штату або локальному). Наприклад, щоб зайняти одну 3 посад в установі локального підпорядкування, досить мати диплом середньої школи або відповідний йому. А проте, деякі роботодавці мають такі вакантні посади, що для їх зайняття потрібно виконати окремі вимоги для кандидатів, наприклад, мати вищу освіту або досвід військової служби. 
Отже, хто ж такий виправник в УВП США? Виправник, або офіцер виправної установи, - це людина у формі, яка відповідальна за спостереження, охорону й безпеку ув'язнених у в'язниці або установі з аналогічним режимом. Зазвичай вони відповідальні за контроль порядку виконання та відбування покарань заарештованими, взятими під варту й засудженими до позбавлення волі особами. Крім того, їм необхідно мати навички проведення соціально-виховної роботи, а також вони несуть відповідальність за безпеку самої УВП. Більшість виправників наймаються управлінням того рівня підпорядкування, в якому перебуває установа, хоча деякі працюють і в приватних в'язницях.

Федеральне бюро в'язниць (eng. Federal Bureau of Prisons) $є$ федеральним відомством при Міністерстві юстиції США, що відповідає за нагляд, утримання під вартою та контроль за особами, які перебувають у місцях позбавлення волі. Воно здійснює постійний набір співробітників у 122 населених пунктах і набирає в середньому 350 нових співробітників щомісяця. Як агентство, орієнтоване на кар'єрне зростання співробітників, воно пропонує широкий спектр цікавих кар'єрних можливостей, які сприяють професійному зростанню. Список доступних вакансій завжди поновлюється та $є$ у вільному доступі на сайті “USAJobs” [14].

Опрацьована література й проведений аналіз ринку праці вакансій у пенітенціарній системі США дає нам підстави стверджувати, що ступінь бакалавра 3 «Кримінального правосуддя» або «Кримінології» $€$ найбільш бажаним для зайняття посади й подальшої професійної діяльності виправника. Програми підготовки бакалаврів «Кримінального правосуддя» США спрямовані на створення системи заходів для боротьби зі злочинністю, зокрема для виявлення злочинів, розшуку, затримання та покарання злочинців. Своєю чергою програми підготовки фахівців «Кримінології» спрямовані на «анатомію злочину», вивчення його причин, умов і наслідків. Студенти зі спеціальності «Кримінальне правосуддя» вивчають компоненти системи кримінального правосуддя та правоохоронних систем, у той час, як студенти 3 напряму «Кримінологія» опановують моделі поведінки злочинців, детермінанти злочинів, статистичний аналіз і соціально-кримінальні тенденції. Іншими освітніми програми бакалаврату, які роботодавці співробітників виправних установ вважають актуальними, $є$ : «Психологія», «Соціологія», «Консультування» та інші програми з галузі поведінкових наук.

$\mathrm{У}$ той час, коли здобуття ступеню бакалавра безумовно є кращою умовою для кандидата на роботу, існують й інші варіанти здобуття освіти. Ступінь бакалавра - це чотирирічна освітня програма в коледжі або університеті. У США також існує багато навчальних закладів, котрі пропонують програми для засвоєння ступеня молодшого спеціаліста в галузі кримінального правосуддя. Здобуття ступеню молодшого спеціаліста, як правило, займає два роки. Окрім того, натепер існує велике різноманіття професійних шкіл, що пропонують сертифікати в галузі кримінального правосуддя. Сертифікат є свідченням того, що кандидат на посаду виправника пройшов спеціальну форму навчання та підготовлений для роботи в УВП. Програми сертифікації, зазвичай, займають менше ніж рік, але кандидати не отримують такі широкі знання в порівнянні з тими, хто отримує ступінь бакалавра або магістра. Претенденти на посаду, які розглядають програму сертифікації як основу для здобуття освіти, мають бути дуже уважними й обережними, оскільки програми сертифікації рідко контролюються державними органами, що відповідають за освіту [20]. 
Варто констатувати, що ми живемо в суспільстві, де технології $€$ дуже важливою частиною будь-якої сфери життя, слід завжди бути на одній хвилі з прогресом в усіх сферах життєдіяльності, не виняток і юридична. Дослідивши американські науково-популярні й фахові видання, такі, як Popular Science, International Journal of Law, Crime and Justice, The Economist, i Lawyer monthly, ми дійшли висновку, що заклади освіти, що надають освіту кандидатам на зайняття посад виправників, роблять акцент на отриманні навичок оперування сучасними перспективними технологіями. Відповідно до публікацій сучасного американського науково-популярного журналу "Popular Science", такими технологіями $€$ штучний інтелект, віддалена присутність або віртуальна реальність, і вони натепер $€$ полем діяльності для ділової конкуренції [21]. Найпрогресивніші виші США вже практикують формат домашніх завдань для студентів-юристів, де замість написання реферату пропонується створити власного бота, наповнити його навчальною інформацією та відправити на «інтерв'ю» викладачеві. Україна теж може похвалитись таким ботом [1]. Отже, ми бачимо, що сучасні технології формують практику права й змінюють спосіб надання юридичних послуг. Таким чином, студенти, які опановують юридичні науки, повинні працювати над розвитком відповідних навичок і компетенцій, а можливість демонструвати технологічну складову частину освіти $€$ все ціннішим доповненням до набору вмінь, які допоможуть їм виділитися. Американські науковці вважають, що виправники мають вміти оперувати технологіями хоча б на базовому рівні, насамперед мається на увазі IT-технології, такий софт, як Microsoft Office, Adobe Acrobat i Connect. А отже, юридична школа - це чудова можливість ознайомитись і застосувати на практиці
IT-інструменти, що дають необхідне базове уявлення юристу про нові корисні технології. До списку необхідних навичок, що будуть корисні у виконанні обов'язків виправника, слід віднести:

1) складання документів (судових доповідей, угод, контрактів та ухвал). Вміння працювати в сервicax Office 365 i Google Drive, що своєю чергою створює можливість дистанційної співпраці 3 іншими фахівцями;

2) вміння створення ефективної nрезентаціï чи плакату в Microsoft PowerPoint або в Prezi для залучення до розробки різного роду конференцій чи навчальних заходів;

3) знання про особливості й функціональність баз даних Microsoft Excel для зручного оперування даними;

4) вміння бути впевненими користувачами інструментів комунікаціі в Інтернеті задля ефективної співпраці з колегами;

5) штучний інтелект або машинне навчання «AI» комп'ютерна технологія, що спрямована на тиражування розумної поведінки людини за допомогою віртуальних помічників, які допоможуть проаналізувати законодавство й скласти необхідний документ;

6) розумні контракти - це сфера, в якій блокчейн-мережі можуть використовуватися для автоматичного примусового виконання переговорів чи укладання угод.

Тому слушною є позиція окремих авторів про те, що роботодавці очікують, що їх співробітники в кінцевому результаті матимуть базові технічні навички, які на тлі сучасного юридичного ландшафту, що швидко розвивається, дадуть змогу фахівцям бути в курсі того, як технології змінюють юридичну практику [15].

Водночас доцільно було б скористатися досвідом Федеральної служби пробації та досудових послуг США. Позитивне, на наш погляд, 
те, що Федеральна служба пробації та досудових послуг США ставить вимогу про необхідність навчання персоналу $з$ першого дня роботи й продовження навчання впродовж всієї кар'єри, а також організовує розвиток отриманих знань у певних сферах діяльності. Федеральний судовий центр і науково-освітне агентство судової системи розробляє навчальні програми й пропонує семінари, майстер-класи, очні й онлайн конференції, супутникові ТВ-трансляції, курси лідерства й нові програми супервізора [12].

Слід звернути увагу й на наявність і функціонування спеціальних підрозділів у пенітенціарній системі США. Так, більшість УВП США мають відділи швидкого реагування, які виконують функціі, тотожні до функцій "SWAT" у поліції, але дещо толерантніші щодо в’язнів, а саме тому попередній військовий досвід бажаний і свідчить про те, що претендент на зайняття посади має низку позитивних навичок і компетентностей, які можуть йому знадобитися, а саме: дисциплінованість, спеціальна підготовка, належна фізична форма й емоційна стійкість. Попередній військовий досвід дає необхідне уявлення про субординацію, що також дуже часто зустрічається у виправних установах. Мало того, службова підготовка, що проводиться в УВП США, зазвичай містить такі дисципліни: «Порядок і практика застосування сили, спеціальних засобів і вогнепальної зброї», "Самозахист», «Перша допомога», “CPR”, «Ведення службової документації, «Судова справа», «Майстерність розряджати обстановку й зменшувати агресію», «Стратегії розв'язання конфліктів», «Виправно-трудове законодавство», «Кримінальне право», «Кримінально-виконавче право», «Розкриття злочинів», «Майстерність перемовин», «Командна робота» й деякі інші тренінги, наприклад: «Подолання психологічної кризи ув'язнених і намірів суїциду», «Дії в екстрених ситуаціях», вивчення Закону «Про охорону праці», «Переговори щодо звільнення заручників», «Боротьба з вживанням наркотиків», «Програми реабілітації засуджених» [18]. Відзначаючи безсумнівну ефективність і доцільність вищезазначених підрозділів в організації повноцінної діяльності УВП США, хочемо наголосити на доречності військового аспекту підготовки виправників у контексті якісного забезпечення фахового зростання фахівців ДКВС України.

Хоча в Україні підготовка фахівців УВП ДКВС України, відповідальних за виправлення та охорону засуджених, наразі перебуває на шляху реформування та постійного вдосконалення [4], ми прагнемо врахувати кращий досвід провідних країн Європи й США й на їх основі зробити пропозиції до нормативних актів, що наразі знаходяться на шляху розробки. За результатами проведеного нами анонімного опитування психологів відділів соціально-виховної та психологічної роботи УВП і слідчих ізоляторів ДКВС України, старших оперуповноважених працівників УВП і слідчих ізоляторів, які проходили курси первинної професійної підготовки в Академії Державної пенітенціарної служби України (далі - Академії ДПтС) щодо якості робочої навчальної програми, за якою їх готують до виконання службових обов'язків, ми визначили, що найголовнішим для подолання сучасних викликів на робочих місцях опитуваних $є$ використання нестандартних підходів і більше застосування інформаційно-комунікаційних технологій (далі - IKT).

Порівняймо основні складові частини освітньої програми (далі ОП) бакалаврського рівня Академіі ДПтС і візьмемо до прикладу ОП Школи соціальної роботи й кримінальної юстиції Вашингтонського університету міста Такоми, США [3; $9 ; 10]$ : 


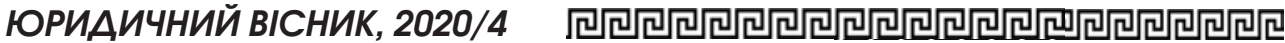

ОП зі спеціальності 081 «Право» Академія ДІІ С України

Цикл професійної підготовки здобувача містить дисципліни обсягом від 5 до 10 кредитів ЕСTS, зокрема:

- Теорія держсави й права;

- Історія держсави й права Украйни;

- Історія держсави й права зарубіэсних країн;

- Конституційне право зарубіэнних країн;

- Конституційне право Украӥни;

- Цивільне й сімейне право;

- Кримінальне право;

- Римське право

- Господарське право;

- Адміністративне право й процес;

- Фінансове право;

- Екологічне право;

- Мізниародие право;

- Трудове право;

- Криміналістика;

- Кримінальний процес;

- Цивільний процес;

- Кримінально-виконавче право; - Кримінологія.
ОП «Кримінальне правосуддя»

Школа соціальної роботи й кримінальної юстиції

Вашингтонського університету міста Такоми, США

Цикл основних курсів Вашингтонського університету містить курси обсягом 5 кредитів ЕСТS коэсен, зокрема:

- Колізія правових норм і соціальна справедливість у кримінологї;

- Психічне здоров'я, вживання наркотичних речовин і система кримінального правосуддя;

- Кримінологічна теорія;

- Встуи до досліджсень соціального забезпечення

(Необхідна умова: вступний

курс статистики $(2,0 /$ С або вище)

протягом останніх 5 років);

- Поліція та суспільство

- Допомізсні навички в системі кримінальної юстиції

(Необхіда умова: курс - колізія правових норм і соціальна

справедливість у кримінологіi);

- Виправлення дорослих;

- Американські кримінальні суди;

- Семінар останнього року навчання: Професіоналізм та етичні питання кримінального судочинства.

Продовжуючи дослідження освітніх компонентів ОП «Кримінальне правосуддя» Школи соціальної роботи й кримінальної юстиції Вашингтонського університету міста Такоми (США), розуміємо, що порівнювати вибіркову складову частину американської освітньої програми 3 українською не можна, оскільки в ОП зі спеціальності 081 «Право» Академії ДПтС України їх тільки 23, а в американському аналозі лише блок «комп'ютерні системи й науки» містить 33 дисципліни, кожна 3 яких налічує від 5 до 12, а то й 15 кредитів ECTS. Вибіркова складова частина американської освітньої програми містить 11 таких блоків.

Здійснивши порівняльний аналіз компонентів освітніх програм, варто зауважити, що ОП Академії ДПтС за спеціальністю 081 «Право» (бакалаврського рівня) має багато еквівалентних американській ОП навчальних дисциплін, а отже, українська система підготовки фахівців для потреб ДКВС постійно вдосконалюється та рухається в правильному напрямку. Однак розглядаючи вибіркові компоненти цих програм, ми бачимо, що, хоча

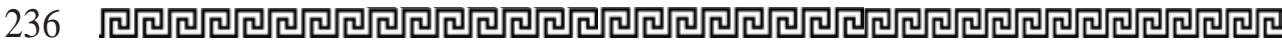


між освітніми можливостями в контексті підготовки фахівців, відповідальних за виправлення засуджених, існує суттєва відмінність, Академія ДПтС України й вища освіта України загалом намагається наблизитися до європейської та американської систем і постійно поривається втілити найкращі зарубіжні практики.

Висновки. Таким чином, проаналізувавши особливості сучасної пенітенціарної системи США, ми визначили, що іï політика в довгостроковій перспективі полягає в зниженні рівня злочинності, а на теперішньому етапі в його стабілізації.

Порівняльний аналіз ОП підготовки виправників показав, що вимоги до підготовки фахівців пенітенціарної системи США постійно підвищуються. Ми підтримуємо думку українських науковців відносно вимогливого ставлення до відбору та якісної підготовки фахівців ДКВС України [5] й хочемо додати, що без належної підготовки виправників проведення реформування цієї служби в Україні неможливе. Безумовно, опрацьований позитивний досвід американських центрів із підготовки персоналу довів нам необхідність постійного вдосконалення своїх освітніх програм. Результати опитування працівників установ виконання покарань і слідчих ізоляторів, а також порівняльний аналіз освітніх програм визначили для нас важливість залучення сучасних методів та IKT для підготовки персоналу, що можна досягти шляхом розширення вибіркової складової частини освітніх компонентів вітчизняних освітніх програм.

Реформування пенітенціарної системи України потребуе підвищення вимогливості підготовки персоналу установ виконання покарань. Незважаючи на значну кількість наукових досліджень, присвячених вивченню різних аспектів підготовки співробітників Державної кримінально-виконавчої служби України, необхідно констатувати, що виклики сучасності й технологічний прогрес вносять свої корективи до забезпечення повноцінного функціонування цієї служби.

Мета наукової статmі полягає у вивченні й визначенні сучасних тенденцій розвитку пенітенціарної системи Сполучених Штатів Америки, в тому числі в здійсненні порівняльного аналізу компонентів освітніх програм із підготовки персоналу установ виконання покарань України й Сполучених Штатів Америки, що дозволить запропонувати шляхи підвищення якості підготовки персоналу установ виконання покарань Державної кримінально-виконавчої служби Украӥни.

У статmі проаналізовано статистичні дані за останні роки щодо кількості ув'язнених у Сполучених Штатах Америки й досліджено нормативно-правові акти, що поклали початок зменшенню чисельності в'язнів в установах виконання покарань $i$ в перспективі призведуть до збільшення рівня декариеерації по всій країні. Визначено причини підвищення стандартів $і$ вимог до підготовки кадрів пенітенціарної системи Сполучених Штатів Америки й сформовано основні запити роботодавиів до професійної підготовки такого персоналу. У статmі проаналізовано вимоги до підготовки студенmiв-юристів у Сполучених Штаmax Америки, зокрема в контексті набуття ними необхідних компетентностей, що будуть корисні під час виконання обов'язків співробітника установи виконання покарань, відповідального за виправлення засудженого. Здійснено порівняльний аналіз компонентів освітніх програм із підготовки персоналу установ виконання покарань України й Школи соціальнӧ̈ роботи й кримінальної юстицї Вашингтонського університету міста Такоми, Сполучені Штати Америки. 
Підсумовуючи результати, наведено не лище власні висновки, але й побажання працівників установ виконання покарань $і$ слідчих ізоляторів, які проходили курси первинної професійної підготовки в Академії Державної пенітенціарної служби.

Ключові слова: підготовка персоналу, пенітенціарна система, виправлення.

Nesterenko V. Certain aspects of selection and training of U.S. penetantiary staff

Reforming of penitentiary system in Ukraine need increase of requirements to penitentiary personnel training. Despite the big amount of scientific researches devoted to study of various training aspects of State Penitentiary Service staff, it is mandatory to certify that nowadays challenges and technological progress make the adjustments to provide the complete functioning of this service.

This article is aimed at studying and defining modern development tendencies of the US penitentiary system including the comparative analysis of components in the educational programs for correctional officers in Ukraine and the USA and as a result it will allow offering the ways of improving the quality of penitentiary staff training in Ukraine.

The statistic data of the recent years concerning the amount of prisoners in the USA and the research of regulations that started reducing the number of inmates in the penitentiary institutions is analyzed in the article and in perspective it can lead to increasing the level of decarceration all over the country. The reasons of standard rising and the requirements for penitentiary personnel training are defined and the basic employers' demands on professional staff training are formed. The requirements for US Law students training, particularly, in the context of acquiring the mandatory competences that will be useful in executing the duties of penitentiary employees responsible for inmates are analyzed. The comparative analysis of educational programs for correctional officers of Ukraine and the School of Social Work and Criminal Justice in the University of Washington, Tacoma, the USA, is conducted.

Summarizing the results, there are not just personal conclusions but wishes of employees of penitentiaries and pre-trial detention centers who have been taking initial training courses at the Academy of the State Penitentiary Service.

Key words: staff training, penitentiary system, educational programs, correction.

\section{Література}

1. Желтухін E.O. Legal tech: на межі права та технологій. Київ, 2017. Юридична газета. URL: https://yur-gazeta. $\mathrm{com} /$ publications / events / legal-tech-namezhi-prava-ta-tehnologiy.html (Jama звернення: 23.08.2020).

2. Квач А.А. Американские тюрьмь закрываются из-за нехватки заключенHax.Legal.report.2019.URL:https: / / legal. report / amerikanskie-tjurmy-zakryvajutsjaiz-za-nehvatki-zakljuchennyh) (Jama звернення: 17.08.2020).

3. План навчального процесу "Право» Академії ДПтС 2019. Чернігів : Академія ДПтС. URL: http://academysps. edu.ua / wp-content / uploads / 2020/02 / Navchalnij-plan-Pravo-bakalavrat.pdf (дата звернення: 01.09.2020).

4. Про схвалення Кониепиї реформування (розвитку) пенітенціарної системи України : Розпорядження Кабінету Міністрів України від 13 вересня 2017 р. № 654-p / Верховна Рада України. URL: https: / / zakon.rada.gov.ua / laws / show/654-2017-\% D1\%80\#Text (Jama звернення: 13.08.2020).

5. Сикал М.М., Ткаченко О.Г. Кадрове забезпечення Державної пенітенціарної служби. Бюлетень Міністерства юстиuіï України. Київ, 2015. № 4. С. 13-20. URL: http:/ / nbuv.gov.ua/UJRN/ bmju_2015_4_6 (дата звернення: 27.08.2020). 
6. Carson E.A. Data Collected Under the First Step Act, 2019. The Bureau of Justice Statistics 2020. March 2020. URL: https: / / www.bjs.gov/content / pub/pdf / dcfsa19.pdf (Last accessed: 26.08.2020).

7. Carson. E.A. Prisoners in 2018. The Bureau of Justice Statistics 2020. April 2020. URL: https://wrw.bjs.gov/ content/pub/pdf/p18.pdf (Last accessed: 27.08.2020).

8. Correctional officer careers \& degrees. How to Become a Correctional Officer. Learn How to Become. 2020. URL: https: / / www.learnhowtobecome.org / correctionalofficer/ (Last accessed: 31.08.2020).

9. Criminal Justice Curriculum. Washington, DC : UW Tacoma. School of social work \& criminal justice. URL: https: / / ww.tacoma.uw.edu / cj / curriculum (Last accessed: 02.09.2020).

10. Detailed course offerings (Time Schedule). Washington, DC : UW Tacoma. School of Engineering \& Technology. URL: https: / / www.washington.edu/students / crscatt/tinfo.html (Last accessed: 03.09.2020).

11. Fasman J. Why does America have such a big prison population? The Economist. August 15, 2013. URL: http: / / ww economist.com / blogs / economist-explains / 2013/08/economistexplains-8 (Last accessed: 23.06.2020)

12. Federal Probation and Pretrial Officers Association. URL: https: / / www. fppoa.org (Last accessed: 03.03.2020).

13. Highest to Lowest - Prison Population Rate. London : World Prison Brief. URL: https: / / www.prisonstudies.org / highestto-lowest / prison_population_rate?field_ region_taxonomy_tid=All\#tabletop (Last accessed: 01.09.2020).

14. Recruitment Incentive Extended through December. Washington, DC: Federal Bureau of Prisons 2019. URL: https:// www.bop.gov/resources / news / $20190912_{-}$ recruitment_incentive_location_update.jsp (Last accessed: 17.04.2020)

15. Ryan F. 7 Key Tech Skills For Law Students. Lawyer monthly. November 27, 2018. URL: https: / / www lawyer-monthly. $\mathrm{com} / 2018 / 11 / 7$-key-tech-skills-for-lawstudents / (Last accessed: 18.05.2020).

16.S.1789 - Fair Sentencing Act of 2010. Washington, DC : Law Library of Congress URL: https://www.congress. gov/bill/111th-congress/senatebill/1789 (Last accessed: 02.09.2020).

17. The Rockefeller Drug Laws. 1973. New York : The Blanch Law Firm. URL: https: / / ww.theblanchlawfirm.com / practice-areas / other-matters-we-handle/ the-rockefeller-drug-laws / (Last accessed: 02.06.2020).

18. Tracy S.J. The construction of correctional officers : Layers of emotionality behind bars. Qualitative Inquiry. 2004. Vol. 10. P. 509-533. DOI: https:// doi.org / 10.1177 / 1077800403259716.

19. Walmsley R. World Pre-trial/ Remand Imprisonment List. London : Institute for Crime \& Justice Policy Research. November, 2018. URL: https://www. prisonstudies.org / sites / default / files / resources / downloads / world_pre-trial_ list_4th_edn_final.pdf (Last accessed: 01.09.2020).

20. What are the education requirements to become a correctional officer? CorrectionalOfficer.org. URL: https: / / www.correctionalofficer.org / faq / educational-requirements (Last accessed: 28.07.2020).

21. Whittaker G.C. British Jurors Can Now Visit Crime Scenes In Virtual Reality. Popular Science. May 25, 2016. URL: https: / / www.popsci.com/uk-usingvr-headsets-for-jurors / (Last accessed: 01.09.2020). 